\title{
ALGORITMA ASTRONOMI MODERN DALAM PENENTUAN AWAL BULAN QAMARIAH (Pemanfaatan Komputerisasi Program Hisab dan Sistem Rukyat On-Line)
}

\author{
Nurul Laila \\ Fakultas Syari'ah UIN Maliki Malang \\ Email: laila_nurul09@yahoo.co.id.
}

\begin{abstract}
Abstrak
The issue of the beginning of new month in hijri calendar, particularly often involves many aspects theologically and scientifically such as astronomy. This involvement aims at minimizing the difference on determining the beginning of month. This article tries to advance astronomy, from scientific aspect, as one of the ways to minimize, not to say eliminate, the difference in determining the beginning of hijri new month. This study refers to the development of modern astronomy, especially with special reference to on-line computerized technology, that plays a pivotal role in the development of hisab and rukyat. This article does not, however, provide detailed exposition about the issue. The writer has, rather, one end in sight, that is, to open up the mindset that hisab-rukyat manage to collaborate with information technology
\end{abstract}

Masalah penentuan awal bulan qamariah melibatkan berbagai aspek yang saling berkaitan secara kompleks baik secara teologis maupun ilmiah seperti aspek astronomi. Dengan melibatkan aspek astronomi dari sisi ilmiah kemungkinan perbedaan penentuan awal bulan dapat diminimalisir agar tidak terus meluas. Di dalam tulisan ini dikemukakan tentang bentuk perkembangan astronomi modern yang berperan untuk perkembangan hisab dan rukyat yang dibalut dengan tekhnologi komputerisasi on-line. Perpaduan hisab-rukyat koputerisasi on-line diharapkan mampu menjadi salah satu solusi alternatif dalam mempersatukan perbedaan yang ada. Dalam tulisan ini memang tidak dijelaskan secara detail namun harapan dari penulis agar dengan wacana yang ada mampu membuka wawasan bagi masyarakat luas. Bahwasanya hisab-rukyat mampu berkoloborasi dengan Informasi teknologi.

Kata Kunci: Algoritma Astronomi, Observational Science, Awal Bulan Qamariah

Islam adalah agama rakhmatan lil 'alamin, yang berkembang pesat hampir di pelosok penjuru dunia, dengan konsep persamaan serta ukhuwah islamiyah yang selalu diagung-agungkan dan hal ini sudah menjadi bagian pada diri Islam itu sendiri. Masyarakat lslam pun ikut berkembang seiring perjalanan ruang dan waktu, namun hal itu bukan berarti menjamin tidak ada problem dalam diri Islam, perselisihan dan perbedaan tetaplah ada. Salah satu diantaranya adalah fenomena perbedaan 1 Syawal yang tidaklah asing di telinga kita yang mayoritas beragama Islam. Dari masa ke masa, umat Islam selalu berselisih mengenai penentuan 1 Syawal guna menetapkan kapan mereka harus mulai mengumandangkan takbir kapan pula saatnya mereka harus mulai berhari raya dan melaksanakan shalat Idul Fitri.
Diskursus bulan Qamariyah, terutama penentuan awal Syawal adalah persoalan yang paling sering diperdebatkan, mengingat hari raya Idul Fitri adalah hari yang memiliki momentum kegembiraan bagi masyarakat muslim, kali ini tidak hanya bermakna sebagai berakhirnya ritus ibadah di bulan puasa, akan tetapi hari kemenangan yang fitri serta dirayakan di seluruh dunia, tidak ketinggalan pula masyarakat Indonesia. Namun sebagian umat Islam merasa dihantui dengan perbedaan ketika kita melihat fenomena penentuan 1 syawal dari berbagai organisasi masyarakat dan pemerintah seakan membuat resah masyarakat awam pada umumnya sehingga hari raya Idul Fitri terasa kurang khidmat dengan adanya perbedaan itu, selain itu kita semua tahu bahwasanya hari besar Islam yang salah satunya Idul Fitri adalah simbol persatuan umat Islam. 
Pada dasarnya perbedaan 1 Syawal adalah persoalan yang menarik dikaji, karena dataran teorinya sama namun pada dataran implementasinya berbeda. Selain itu perbedaan 1 Syawal menurut Ibrahim Hosen merupakan persoalan klasik yang senantiasa aktual. Klasik karena persoalan ini semenjak masa awal Islam sudah mendapatkan perhatian dan pemikiran cukup serius dari pakar hukum Islam, dan terkait erat dengan perbagai ibadah serta melahirkan pendapat yang bervariasi. Disebut aktual karena hampir di setiap tahun terutama menjelang penentuan 1 Syawal, persoalan ini selalu muncul dan mengundang polemik sehingga nyaris mengancam pilar kesatuan dan persatuan umat Islam. ${ }^{1}$

Di sisi lain dalam perkembangan keilmuan saat ini, kemajuan keilmuan terkait benda-benda langit yang sering diistilahkan dengan astronomi ${ }^{2}$ serta teknologi itu sendiri semakin berkembang dengan sangat pesat. Hisab (perhitungan astronomi) dan rukyat (pengamatan astronomi) secara umum adalah bagian tak terpisahkan dari astronomi modern. Hisab formulasinya diperoleh dari hasil rukyat jangka panjang digunakan dalam pembuatan almanak. ${ }^{3}$ Almanak astronomi sendiri merupakan salah satu produk evolusi pengetahuan manusia yang memungkinkan manusia tidak selalu setiap saat memperhatikan langit. Keteraturan dilangit telah dirumuskan secara sistematik didalamnya sehingga memudahkan orang dalam memperkirakan fenomena astronomis, terutama setelah ditemukan teknologi alternatif seperti perangkat komputer serta softwaresoftware yang mampu diakses setiap saat dalam penyajian fenomena astronomis.

Kemajuan di bidang astronomi saat ini telah memasuki era modern yang memungkinkan kita untuk menentukan posisi benda-benda langit dengan ketelitian tinggi, termasuk didalamnya penentuan posisi bumi, bulan dan matahari. Perkembangan astronomi modern ini dapat dimanfaatkan untuk membantu menentukan awal bulan Islam, yang sampai saat ini

1 Ibrahim Hosen, Tinjauan Hukum Islam Terhadap Penetapan Awal Bulan Ramadhan, Syawal, Dan Dzulhijjah, Makalah Seminar Sehari Tentang Penetapan Awal Ramadhan, Syawal, dan Dzulhijjah.internet Website: http://www.masjidrayavip.org. Diakses pada tanggal 9 November 2009, Jam 06:00 WIB. Lihat juga Ahmad Izzuddin, "Kapan 1 Ramadhan 1418 H Jatuh?," Suara Ummat, Vol 1, No 2, Desember 1997, 49-50, Lihat serta Ahmad Izzudin, Fiqih Hisab Rukyat, (Jakarta: Erlangga, 2007). h.2

2 Astronomy is a natural science that deals with the study of celestial objects (such as stars, planets, comets, nebulae, star clusters and galaxies) and phenomena that originate outside the Earth's atmosphere (such as the cosmic background radiation). It is concerned with the evolution, physics, chemistry, meteorology, and motion of celestial objects, as well as the formation and development of the universe. Internet: website, http://en.wikipedia.org/wiki/ Astronomy

3 Thomas Djamaludin, Hisab rukyat Di Indonesia, serta permasalahanya, (Jakarta: BMKG, 2010). h.3 masih merupakan problematika yang dihadapi umat Islam.

Beriringan dengan kemajuan di bidang astronomi, perkembangan teknologi komputer telah mencapai kemajuan yang spektakuler. Kemajuan di bidang komputer ini juga dapat dimanfaatkan untuk mewujudkan program komputer untuk membantu menentukan awal bulan Islam. Program ini ditulis dengan bahasa pemrograman yang mampu mengimplementasikan rumus/model yang berkembang di astronomi modern. Untuk dapat menghasilkan program komputer yang baik diperlukan Algoritma yang baik pula, sehingga program tersebut menghasilkan perhitungan yang akurat dan cepat. ${ }^{4}$

Tulisan ini memberikan gambaran secara sepintas atau global tentang algoritma yang disusun untuk pembuatan program komputer yang berbasis pada rumus/model astronomi modern sehingga dapat dipakai untuk membantu penentuan awal bulan dalam Islam. Dengan harapan mampu menjadi gambaran dalam perkembangan Falak dan hisab rukyat itu sendiri.

\section{Pembahasan}

Perbedaan penentuan awal bulan Qamariah adalah faktor yang paling menuai kontroversial dibanding materi-materi ilmu falak yang lain misalnya penentuan arah kiblat, waktu sholat, dan gerhana. Awal bulan Qamariah adalah salah satu faktor yang paling dominan kemugkinan terjadi pergolakan dibanding materi ilmu falak yang lain, hal ini sudah tidak asing lagi di masyarakat. Pada dasarnya awal bulan Qamariah memang harus ditetapkan, karena hal ini erat kaitannya dengan pelaksanaan ibadah yang harus dilakukan umat Islam. Dasar penetapan awal bulan Qamariah ini antara lain firman Allah:

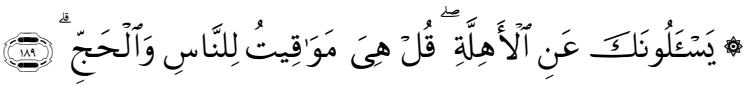

Artinya:

Mereka bertanya kepadamu tentang bulan sabit. Katakanlah: "Bulan sabit itu adalah tanda-tanda waktu bagi manusia dan (bagi ibadat) haji.

Dari tahun ke tahun sering mengalami adanya perbedaan di kalangan umat Islam dalam menentukan awal bulan Qamariah terutama bulan-bulan yang mengandung unsur-unsur ibadah, bahkan hal

4 Khafid, Algoritma Astronomi Modern Dan Penentuan Awal Bulan Islam Secara Global. (Makalah disajikan pada Seminar Dan Workshop Nasional: aspek Astronomi Dalam Kalender Bulan dan Kalender Matahari. Senin 13 Oktober. 2003). 
ini tidak hanya terjadi di Indonesia namun juga di belahan negara-negara lain. Keadaan tersebut tidak jarang menjadi keresahan bagi umat Islam dan dapat mengganggu ukhuwah islamiyah.

Pertanyaan-pertanyaan yang timbul seperti ini adalah mengapa perbedaan itu sering berulang, apakah para pemimpin tidak melakukan suatu tindakan apapun, usaha apa dan solusi apa yang telah ditempuh serta kendala apa yang terjadi sehingga mengganjal penyatuan tersebut. Anehnya lagi mengapa perbedaan tersebut hanya pada bulan-bulan tertentu saja, namun untuk bulan-bulan yang lain banyak yang mengikuti pemerintah. Kalaupun dijawab dengan karena mengandung nilai ibadah hal tersebut menurut penulis adalah alasan yang terlalu sederhana, hal ini lebih banyak disebabkan karena perbedaan tersebut lebih diwarnai dengan kuatnya pengaruh organisasi masyarakat Islam dalam proses penentuan awal bulan Qamariyah tersebut.

Di Indonesia sudah sering terjadi adanya perbedaan tanggal satu pada bulan Qamariyah. Jelas hal ini membuat persatuan umat Islam terganggu, bahkan tidak hanya bertentangan paham saja namun kadang perbedaan tersebut dapat menimbulkan pertentangan fisik. Sudah barang tentu hal ini sangat memprihatinkan umat Islam yang mayoritas di negeri ini. ${ }^{5}$ Masyarakat luas pada umumnya, hanya mengetahui bahwa perbedaan penetapan hanya antara hisab dan rukyat. Hal Itu memang benar, namun perbedaan antara hisab dan rukyat tidak merupakan satu-satunya penyebab, bahkan jika diperhatikan lebih jauh perbedaan antara intern hisab dan rukyat sendiri. Selebihnya perbedaan juga timbul karena ada banyak golongan-golongan yang memiliki metode sendiri dalam menentukan awal bulan Qamariyah.

Bagi umat Islam, pembahasan tentang penentuan awal bulan Qamariah bukan saja merupakan hal yang penting, tetapi sekaligus juga masalah yang cukup pelik dan mengandung banyak faktor permasalahan. Dikatakan penting sekali lagi karena mengandung ibadah, di mana sistem yang digunakan dalam penentuan tersebut adalah sistem bulan yang produknya disebut produk Qamariah. Banyak sekali kegiatan ibadah yang di tentukan dengan sebuah tanggal atau kalender seperti penentuan bulan Ramadhan, Syawal, Idul Adha, membayar zakat. Sedangkan kalender di tentukan dengan awal bulan yang saat ini masih ramai di bicarakan masyarakat terutama tentang penentuan awal bulan Qamariah.

5 Departemen Agama, Almanak Hisab Rukyat, (Jakarta:Dirjen Pembinaan Masyarakat Islam Kemenag, 2010). h.98
Selain itu dikatakan pelik karena pada kenyataannya, penentuan awal bulan tidak hanya bermasalah pada ranah metode atau kriteria serta masalah agama saja namun lebih dari itu. Ini merupakan masalah yang multidimensional, di samping menyangkut masalah agama namun juga masalah ilmu pengetahuan tekhnologi, sosial, hukum, dah bahkan sudah masuk dalam ranah politik. Dalam ketetapan waktu pelaksanakan ibadah ketentuan syari'at Islam jelas dan tegas tanpa memberikan keleluasan intrepretasi, tetapi berlaku sebaliknya terkait dalam masalah yang sama, syari'at Islam memberikan peluang yang besar untuk intrepretasi sehingga melahirkan sebuah multi tafsir, di sisi yang lain lagi terkait dengan masalah yang sama, tidak ditemukan ketentuan syar'i yang eksplisit.

Pengukuran bulan Qamariah yang didasarkan pada peredaran bulan atau hilal digunakan sebagai penentu waktu ibadah. Hal ini merupakan salah satu kajian ilmu pengetahuan khususnya astronomi atau ilmu falak. Oleh karena itu, ilmu pengetahuan serta teknologinya tidak dapat diabaikan begitu saja bahkan mutlak menjadi dasar pertimbangan dalam menentukan awal bulan Qamariah tidak hanya bersifat individual, tetapi justru lebih bersifat universal. Namun di sisi lain dimensi sosial dalam pengamalan agama yang waktunya mengacu pada bulan Qamariah lebih menonjol. ${ }^{6}$ Ketika dimensi sosial lebih dominan kecenderungan munculnya, perbedaan bahkan konflik lebih besar sehingga memerlukan regulasi-regulasi yang dapat dan cukup kuat untuk mengatur hubungan antar individual dan kelompok dalam masyarakat yang dipengaruhi dimensi sosial. ${ }^{7}$

Akan tetapi peraturan atau regulasi saja sematamata belum cukup, karena peraturan baru efektif apabila peraturan itu memiliki regulasi yang cukup kuat di masyarakat dan dapat menjamin rasa keadilan di masyarakat. Karenanya, pertanyaannya bukan pada isi peraturan tersebut, tetapi juga dari mana peraturan itu lahir, atau bersumber dan untuk apa peraturan itu dilahirkan. Jadi masalah sosial hukum, politik menjadi bagian yang tidak terpisahkan dari masalah penentuan bulan Qamariah. ${ }^{8}$

Ada yang menjelaskan bahwa menurut penanggalan Qamariah hari dimulai setelah terbenamnya

\footnotetext{
6 T. Djamaluddin, Menggagas Fiqih Astronomi, Telaah hisab dan pencarian solusi perbedaan hari saya, (Bandung: kaki langit, 2005). h.38

7 Salam Nawawi, Rukyat Hisab di kalangan NU dan Muhammadiyah, meredam konflik dalam menetapkan hilal, (Surabaya:Diantama, 2004). h. 62

8 Syaiful Anwar, makalah Penentuan awal bulan Qamariyah, (Yokjakarta: majlis tarjih Muhammadiyah, 2008). h.20
} 
matahari. Namun untuk kriteria penentuannya daripada pergantian hari di dalam awal bulan ada beberapa pendapat. Antara lain seperti pergantian bulan Qamariyah apabila ijtima' terjadi sebelum terbenam matahari maka malam itu adalah masuk pada bulan berikutnya. Namun apabila sebaliknya maka besok masih masuk pada bulan yang lama. ${ }^{9}$ Sementara itu, menurut Noor Ahmad, bahwa bulan Qamariah itu dimulai ketika bulan sudah muncul di tempattempat yang berbeda yang disesuaikan dengan posisi matahari. ${ }^{10}$

Adapun pendapat lain mengatakan bahwa manakala matahari terbenam terlebih dahulu daripada bulan, artinya apabila matahari lebih dahulu terbenam maka besok telah dinyatakan masuk bulan baru. Namun jika sebaliknya maka masih masuk pada bulan yang lama. Seperti yang dilansir dalam wikipedia, ${ }^{11}$ penentuan awal bulan (new moon) ditandai dengan munculnya penampakan (visibilitas) bulan sabit pertama kali (hilal) setelah bulan baru (konjungsi atau ijtima'). Pada fase ini, bulan terbenam sesaat setelah terbenamnya matahari, sehingga posisi hilal berada di ufuk barat. Jika hilal tidak dapat terlihat pada hari ke29, maka jumlah hari pada bulan tersebut dibulatkan menjadi 30 hari. Tidak ada aturan khusus bulan-bulan mana saja yang memiliki 29 hari, dan mana yang memiliki 30 hari. Semuanya tergantung pada penampakan hilal.

Tidak dinafikan dalam penentuan awal bulan secara ilmiah ada dua metode hisab dan rukyat. Pada dasarnya kebanyakan masyarakat menginterpretasikan astronomi masuk pada wilayah hisab, meskipun sebenarnya dalam astronomi juga dilakukan pengamatan atau disebut dengan Observational Science. Sebagai ilmu yang mempelajari segala fenomena angkasa, astronomi mendapatkan tempat tumbuh yang subur dikalangan umat Islam.

Haliniadalah wajarkarenamengingat banyaknya ayat-ayat al-Qur'an yang memerintahkan umat Islam untuk memperhatikan langit serta kejadian-kejadian di alam semesta. Sebagai bentuk motivasi untuk selalu meningkatkan iman kita kepada Allah. Dalam konsep Islam benda-benda dan peristiwa yang ada di langit merupakan tanda-tanda keagungan dan kekuasaan Allah S.W.T. lebih jauh lagi ibadah umat Islam sering berkaitan erat dengan astronomi. Contoh penentuan

9 Muhzidin Khazin, Ilmu Falak dalam teori dan peaktek, (Yokjakarta: dunia Pustaka, 2004). h.145

10 Ahmad, N.,Risalah Syamsul Hilal fi Hisab as-Sinin wa al-Hilal wa alIjtima' wa al-Khusuf wa al-Kusuf, (Kudus: Madrasah Thulab Salafiyah, tt). h. 10

11 http://id.wikipedia.org/wiki/Hilal Diakses pada 19 Mei:2011 awal waktu sholat, penentuan awal bulan Ramadhan, Syawal, penentu arah kiblat dan lain sebagainya.

Perkembangan ilmu pengetahuan semakin hari semakin pesat dan juga pernah mencapai keemasannya di zaman Islam. Dengan munculnya nama-nama ilmuwan muslim yang hingga kini diakui sebagai pelopor ilmu pengetahuan dan teknologi seperti salah satunya Ibnu Haitam atau al Hazzen yang namanya diabadikan dalam salah satu kawah di bulan. Hingga selanjutnya Islam mengalami keruntuhan dan ilmu pengetahuan berpidah secara estafet ke dunia barat.

Namun ada sebagian ilmu yang salah satunya ilmu falak tetap berkembang hingga sampai pada bumi Indonesia dan berkembang di dunia pesantrenpesantren. Akan tetapi ilmu falak yang ada perlu di koreksi dengan akurasi yang tinggi dengan teoriteori astronomi yang terus mengalami perkembangan sangat pesat dan akurasi yang tinggi serta dikemas dengan format balutan komputer adalah Algoritma astronomi modern suatu model software untuk hisab dan rukyat.

Pada dasarnya astronomi sendiri merupakan ilmu pengetahuan yang berbasis mengamatan dan observasi (rukyat). Oleh karenanya sebagai ilmu yang berlandaskan observasi semuanya tidak lepas dari pengamatan karena tanpa pengamatan astronomi tidak bisa berkembang dan menghasilkan data-data yang akurat. Observasi memang menduduki tempat yang sangat penting, namun tidak kalah penting pula adalah teori yang berbasiskan perhitungan (Hisab) yang dibuat berdasarkan laporan dari observasi.

Karena dengan hasil observasi yang di hitung dengan teori maka akan dapat memprediksi fenomena yang akan terjadi sehingga dapat dibuat rencana pengamatannya serta tempat dan waktu yang sudah ditentukan dari hasil perhitungan tersebut. Dengan demikian dapat disimpulkan bahwa pemodelan hisab salah satunya dengan algoritma astronomi modern yang disertai para pengamat rukyat yang profesional, terlatih, sering melakukan observasi tidak hanya pada saat awal Ramadhan dan Syawal saja, dan perukyat sendiri memahami akan ilmu pengamatan astronomi (Observational Science) serta benda-benda langit terutama bulan, bumi dan matahari tersebut mulai dari gerak, susunan, dan fase-fasenya serta yang berkaitan, diharapkan mampu menjadi solusi dalam penentuan awal bulan tersebut.

Dalam perkembangan ilmu pengetahuan yang semakin maju banyak sekali teori-teori yang berkembang. Ada beberapa teknik komputerisasi, salah satunya dengan metode algoritma astronomi modern. 
Dalam matematika dan komputasi, algoritma atau algoritme merupakan kumpulan perintah untuk menyelesaikan suatu masalah. Perintah-perintah ini dapat diterjemahkan secara bertahap dari awal hingga akhir. Dapat juga Algoritma adalah logika, metode dan tahapan (urutan) sistematis yang digunakan untuk memecahkan suatu permasalahan. Menurut Muhammad ibn Mūsā al-Khwārizmī algoritma adalah : "Suatu metode khusus untuk menyelesaikan suatu persoalan “. Menurut Goodman Hedet Niemi algoritma adalah: "Urut-urutan terbatas dari operasi terdefinisi dengan baik, yang masing-masing membutuhkan memori dan waktu yang terbatas untuk menyelesaikan suatu masalah". Jadi algoritma adalah : Cara yang dapat ditempuh oleh komputer dalam mencapai suatu tujuan, terdiri atas langkah-langkah yang terdefinisi dengan baik, menerima input, melakukan proses, dan menghasilkan output.

Kata algoritma berasal dari latinisasi nama seorang ahli matematika Islam dari Uzbekistan Al Khawārizmi (hidup sekitar abad ke-9), sebagaimana tercantum pada terjemahan karyanya dalam bahasa latin dari abad ke-12 "Algorithmi de numero Indorum". Pada awalnya kata algoritma adalah istilah yang merujuk kepada aturan-aturan aritmetis untuk menyelesaikan persoalan dengan menggunakan bilangan numerik Arab (sebenarnya dari India, seperti tertulis pada judul di atas). Pada abad ke-18, istilah ini berkembang menjadi algoritma, yang mencakup semua prosedur atau urutan langkah yang jelas dan diperlukan untuk menyelesaikan suatu permasalahan. Beriringan dengan kemajuan dibidang astronomi, perkembangan teknologi komputer telah mencapai kemajuan yang spektakuler. Kemajuan dibidang komputer ini juga dapat dimanfaatkan untuk mewujudkan program komputer untuk membantu menentukan awal bulan Qamariah. Program ini ditulis dengan bahasa pemrograman yang mampu mengimplementasikan rumus/ model yang berkembang di astronomi modern. Untuk dapat menghasilkan program komputer yang baik diperlukan algoritma yang baik pula, sehingga program tersebut menghasilkan perhitungan yang akurat dan cepat.

Dalam proses pengaplikasian algoritma ada beberapa cara agar mampu membuat algoritma yang baik seperti yang disampaikan Ing-khafid dari Bakosurtanal bahwa : Ketika kita berusaha memecahkan masalah penentuan awal bulan Qamariah, dengan metode atau teknik pemrograman komputer yang digunakan untuk memecahkan masalah itu ada kemungkinan bisa banyak (tidak hanya satu). Dan kita harus me- milih mana yang terbaik diantara teknik-teknik pemrograman itu disesuaikan dengan rumus/model penentuan awal bulan Islam menurut astronomi modern. Hal ini sama juga dengan algoritma, yang memungkinkan suatu permasalahan dipecahkan dengan metode dan logika yang berlainan. Lalu bagaimana mengukur mana algoritma yang terbaik?

Beberapa persyaratan untuk menjadi algoritma yang baik terkait dengan pemrograman komputer untuk penentuan awal bulan Islam adalah: (1) Tingkat kepercayaannya tinggi (realibility); hasil yang diperoleh dari proses harus berakurasi tinggi dan benar, (2) Pemrosesan yang efisien (low cost); proses harus diselesaikan secepat mungkin dan frekuensi kalkulasi yang sependek mungkin, sehingga biaya dapat ditekan, (3) Sifatnya umum (general); bukan sesuatu yang hanya untuk menyelesaikan satu kasus saja, tapi juga untuk kasus lain yang lebih umum, (4) Bisa Dikembangkan (expandable); haruslah sesuatu yang dapat kita kembangkan lebih jauh berdasarkan perubahan requirement yang ada, (5) Mudah dimengerti; siapapun yang melihat, dia akan bisa memahami algoritma anda. Susah dimengertinya suatu program akan membuat susah di maintenance (kelola), (6) Portabilitas yang tinggi (Portability); bisa dengan mudah diimplementasikan di berbagai platform komputer.

Adapun beberapa contoh pemrogaman komputerisasi dengan algoritma astronomi modern seperti PrayerCalendar Marker, Islamic Timer for DOS, Muslim Shalat Times, Gregorian-Hijri Dates Converter. Di Indonesia ada mawaaqit, Astro info dan lain sebagainya. Software-software tersebut sudah menggunakan koreksi teori astronomi modern, dan sudah tercover mulai dari kalender, awal waktu sholat, prediksi gerhana serta penentuan arah kiblat. Softwarenya juga dapat di akses via internet.

Namun hal ini bukan berarti tinggal menggunakan software-software yang ada karena software yang ada juga memerlukan revisi-revisi seiring perkembangan keilmuan itu sendiri. Maka dari itu masyarakat terutama para pecinta ilmu falak diharapkan mampu membuat software-software yang berbasis algoritma astronomi modern, dengan aktif mengikuti berbagai pelatihan-pelatihan hisab-rukyat yang diselenggarakan di berbagai daerah baik di dalam maupun di luar negeri.

Setelah mengkaji tentang algoritma astronomi modern sebagai bentuk perkembangan keilmuan kekinian, selanjutnya penulis mencoba memaparkan tentang pemanfaatan komputerisasi program hisab 
dan sistem rukyat on-line. Komputer adalah mesin penghitung elektronik yang cepat dan dapat menerima informasi input digital, kemudian memprosesnya sesuai dengan program yang tersimpan di memorinya, dan menghasilkan output berupa informasi. ${ }^{12}$ Seiring perkembangan zaman yang terus dibarengi dengan perkembangan teknologi informasi, komputer telah menjadi icon dari perkembangan zaman itu sendiri. Seiring dengan berkembanganya teknologi, maka dunia falak juga mulai mengimbangi perkembangan yang ada dengan meciptakan komputerisasi hisab, sebagai bentuk pemanfaatan daripada perkembangan komputer itu sendiri yang juga terus mengalami perkembangan, dan terciptanya software-software yang berbasis algoritma astronomi modern seperti Jordanian Astronomical Society, acurate time serta menghasilkan data yang tingkat akurasinya tinggi. Selanjutnya mampu diakses oleh seluruh lapisan masyarakat di mana pun berada.

Kemudian ketika bicara masalah komputerisasi dalam program hisab, maka berbicara bagaimana menghitung dengan cepat dan akurat yang mempertimbangkan berbagai parameter baik itu dari astronomi, matematik, statistik dan lain-lain dengan memanfaatkan komputer sedemikian rupa sehingga kesalahan manusia dapat diminimalkan. Dengan komputer juga dimungkinkan untuk memasukkan semua parameterparameter perhitungan. Di lain hal, ketika bicara komputerisasi program hilal, maka bicara bagaimana mengoptimalkan pengamatan hilal sedemikian rupa, sehingga hasil yang diperoleh lebih akurat. Dalam hal ini memperhitungkan unsur-unsur pengamat, lokasi, peralatan dan prediksi serta paramater-parameter lain yang mendukung keakuratan hasil pengamatan dengan memasukkan pemanfaatan komputer sebagai sarana bantu untuk keberhasilan rukyat. ${ }^{13}$

Setelah membahas tentang algoritma astronomi modern sebagai basik serta komputerisasi program hisab-rukyat sebagai bentuk pengembangan yang dibalut dengan teknologi yang pada akhirnya tercipta software-software falak, dilanjutkan dengan pemanfaataan teknologi informasi dalam bidang sistem rukyat yang di gunakan pada saat pelaksanaan rukyat dari awal hingga akhir proses pengamatan, dimana dapat diikuti oleh masyarakat luas, yaitu sistem rukyat online. Menurut Hendro, rukyat online mempunyai daya jangkau yang sangat luas, karena dapat diakses

\footnotetext{
12 V. Carl Hamacher, Zvonko G. Vranesic, Safwat G. Zaky, Computer Organization (McGraw-Hill, 2001, 5th Edition)

13 Khafid, Komputerisasi Hisab dan Rukyat (Surabaya: Disampaikan pada kuliah umum, 11-12 Oktober 2002). h.3
}

oleh berjuta-juta manusia melalui koneksi global yaitu internet. Rukyat online merupakan seperangkat instrument pengamatan astronomi yang terdiri atas teleskop dan detektor global yang menghubungkan kepada jaringan internet yang didukung oleh perkembangan piranti lunak saat ini seperti modem dan Wi- $f$ i untuk akses internet dan laptop, ipad serta lain sebagainya. ${ }^{14}$

Sifatnya yang mobile dan robotic juga akan sangat membantu mobilitas pelaksanaan rukyat, manakala kondisinya terganggu oleh cuaca. Pendekatan ini diyakini dapat memberikan manfaat dalam pemahaman dan pendidikan khususnya bidang sains, astronomi dan falak itu sendiri. Potensi pengamatan real-time, mulai persiapan pengamatan, serta proses terjadinya pengamatan hilal di beberapa tempat yang telah disepakati bersama dapat diakses melalui jaringan internet memiliki nilai tambah yang tinggi karena selama ini hanya di liput di televisi dan tidak secara keseluruhan dalam prosesi pengamatan tersebut mengingat masyarakat dunia dengan melintas ruang batas ruang dan waktu, dapat berpartisipasi dan berinteraksi aktif dalam pengamatan hilal dan objek astronomi lainnya. Seperti gambar III di bawah ini:

\section{Gambar I}

Proses Kinerja Komputerisasi Hisab-Rukyat secara Online dengan basik Algoritma Astronomi.

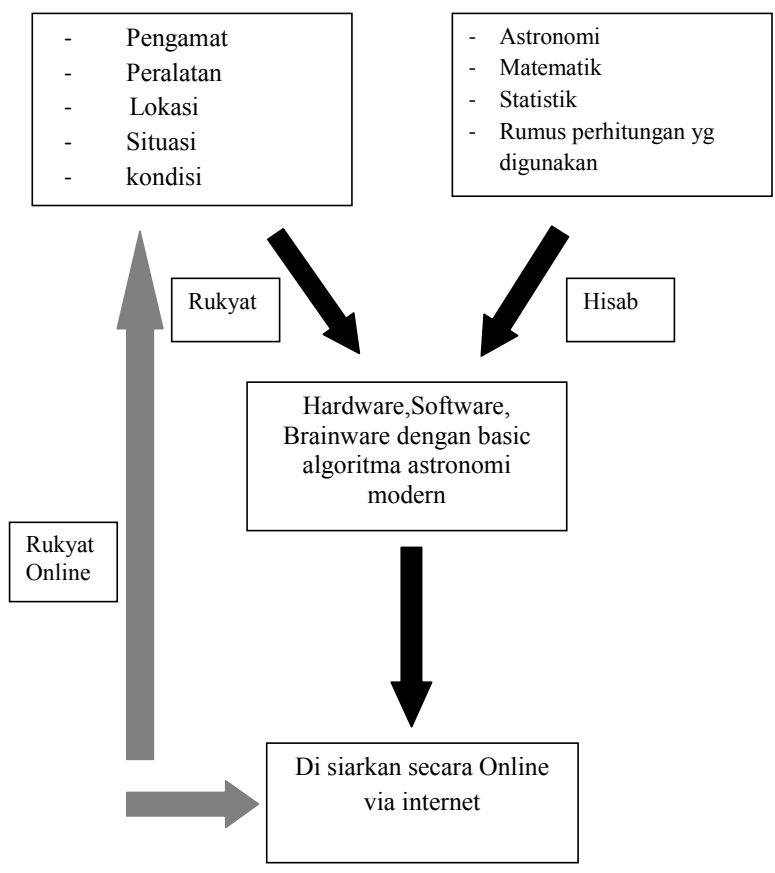

14 Hendro Stayanto, Membaca langit, (Bandung: Al-Ghuraba, 2008). h.45 


\section{Kesimpulan}

Dari penjelasan yang telah dipaparkan maka dapat disimpulkan bahwa antara hisab dan rukyat seharusnya tidak ada lagi perbedaan apabila ditinjau dari sisi ilmiah. Karena pada dasarnya keduanya adalah satu-kesatuan yang utuh, perhitungan hisab jelas membutuhkan data-data yang empiris dari lapangan karena perubahan astronomis selalu terjadi di alam sehingga dibutuhkan observasi (rukyat), sedangkan rukyat sendiri tidak mampu berjalan begitu saja tanpa di pandu oleh hisab sebagai penentu dimana lokasi, letak, arah hilal dan berapa ketinggian yang akan di rukyat pada akhirnya nanti. Astronomi berperan membantu dari aspek ilmiah dengan algoritma astronomi modern yang berkolaborasi dengan pemograman komputer sehingga menghasilkan software-software yang berakurasi baik sehingga dapat dijadikan acuan dalam menentukan awal bulan Qamariah.

Perkembangan teknologi informasi yang berbasis online setidaknya juga mampu dimanfaatkan oleh umat Islam dalam perkembangan sains dan teknologi terutama dalam bidang hisab-rukyat tersebut.

\section{Daftar Pustaka}

Anwar, Syaiful. 2008. Penentuan awal bulan Qamariyah, Makalah disajikan pada Seminar Nasional Majlis Tarjih dan Tajdid Pimpinan Pusat Muhammadiyah Yokjakarta, 29Zulkaidah2 Zulhiijah 1429 H/ 27-30 November.

Ahmad, N. Tt. Risalah Syamsul Hilal fi Hisab asSinin wa al-Hilal wa al-Ijtima'wa al-Khusuf wa al-Kusuf. Kudus: Madrasah Thulab Salafiyah.

Djamaludin, Thomas. 2010. Hisab rukyat Di Indonesia, serta permasalahanya. Jakarta: BMKG.

Djamaludin, Thomas. 2005. Menggagas Fiqih Astronomi, Telaah hisab dan pencarian solusi perbedaan Hari Raya. Bandung: kaki langit.

Departemen Agama. 2010. Almanak Hisab Rukyat. Jakarta: Dirjen Pembinaan Masyarakat Islam Kemenag.

Hamacher, V. Carl Zvonko G. Vranesic, Safwat G. Zaky. 2001. Computer Organization. McGrawHill, 5th Edition.

Izzudin, Ahmad. 2007. Fiqih Hisab Rukyat. Jakarta: Erlangga.

Izzudin, Ahmad. 1 Desember 1997. “ Kapan 1 Ramadhan 1418 H Jatuh?," Suara Ummat . Vol 1, No 2, 49-50.

Khafid. 2002. Komputerisasi Program Hisab dan sehingga diharapkan masyarakat tahu secara real-time akan proses rukyat itu sendiri, yang juga dibarengi oleh perukyat yang profesional memahami akan teori-teori astronomi dengan objek benda langit yang akan dirukyat serta terlatih dalam hal observasi atau rukyat, tidak hanya merukyat saat awal Ramadhan dan Syawal saja sehingga menghasilkan data yang akurat.

Demikian sedikit pemaparan dari penulis dan berharap pencerahan-pencerahan intelektual senantiasa ditumbuhkembangkan untuk memperkokoh budaya keilmuan tanah air. Kami percaya bangsa yang besar adalah bangsa yang memiliki apresiasi tinggi atas ilmu pengetahuan. Sains pada hakekatnya adalah rasional yang menjujung tinggi kejujuran sehingga masyarakat yang mengerti agama dan sains semestinya juga masyarakat yang rasional dan berbudi pekerti luhur. Karena berfikir rasional dan ilmiah adalah bagian dari pencerahan. Sesungguhnya kegelapan hanya mampu di terangi oleh agama dan sains.

Rukyat, Makalah Disajikan pada kuliah umum: Komputerisasi Program Hisab dan Rukyat. Surabaya:11-12 Oktober.

Khafid, 2003. Algoritma Astronomi Modern Dan Penentuan Awal Bulan Islam Secara Global. Makalah disajikan pada Seminar dan Workshop Nasional: aspek Astronomi dalam Kalender Bulan dan Kalender Matahari. Senin 13 Oktober.

Khazin, Muhzidin. 2004. Ilmu Falak dalam teori dan Praktek. Yokjakarta: Dunia Pustaka.

Meeus, Jean. 1991. Astronomical Algorithms. Virginia : Willman Bell, Inc.

Nawawi, Salam. 2004. Rukyat Hisab di kalangan NU dan Muhammadiyah, meredam konflik dalam menetapkan hilal. Surabaya: Diantama.

Nashirudin. 2009. Menelusuri Pemikiran Mohammad Shawkat Odeh (Sebuah Studi Awal). Makalah disajikan pada Seminar Nasional Ikatan Alumni ITB dan Keluarga Mahasiswa Muslim Astronomi An-Najm ITB, Di Obeservatorium Boscha pada 19 Desember.

Stayanto, Hendro. 2008. Membaca langit. Bandung: Al-Ghuraba.

Zubair, U. J. Tt. al-Khulasah al-Wafiyah fi al-Falak 
bi Jadwal al-Lughoritmiya. Kudus: Menara Kudus.

Ibrahim Hosen, Tinjauan Hukum Islam Terhadap Penetapan Awal Bulan Ramadhan, Syawal, Dan Dzulhijjah, Makalah Seminar Sehari Tentang Penetapan Awal Ramadhan, Syawal, dan Dzulhijjah.(Online) (http://www.masjidrayavip.
org/index\&Itemid=98 Diakses pada tanggal 9 November 2009, Jam 06:00 WIB )

Astronomy. (Online) : website, (http://en.wikipedia. org/wiki/Astronomy Diakses pada 8 Mei 2011) Hilal, (Online) : (http://id.wikipedia.org/wiki/Hilal Diakses pada 19 Mei 2011) 